УДК 330

DOI: https://doi.org/10.26642/jen-2019-3(89)-79-86

М.М. Радсва, д.е.н., проф.

Мелітопольський інститут державного та муніципального управління «Класичного приватного університету»

\title{
Стратегічний механізм забезпечення конкурентоспроможності економічного суб'скта на національному та міжнародному рівнях
}

У роботі з використанням системного підходу запропоновано кониептуальний підхід до стратегічного механізму забезпечення конкурентоспроможності економічного суб'єкта, який являє собою систему поглядів на рушійні сили та методи досягнення мети підприємства через методологічне обгрунтування формування, впровадження та оцінки соціально-економічного ефекту конкурентної політики. Підхід охоплює питання обтрунтування можливості та необхідності управління прочесами забезпечення конкурентоспроможності на рівні економічного суб'єкта; ідентифікацію об'єкта $і$ суб'єкта, видів стратегії забезпечення конкурентоспроможності. Одним з елементів $є$ дії з формування методологічної основи управління стратегією забезпечення конкурентоспроможності економічного суб'єкта. Механізм управління стратегією, базуючись на принципах $і$ методах управління, забезпечує сочіально-економічний ефект від упровадження конкурентної стратегї через формування та реалізацію конкурентної політики. Мету підприємства структуровано у вигляді ієрархічного ланцююка проміжних результатів, для досягнення яких розроблено систему стратегій: стратегічна перспектива (зростання, стабілізація, скорочення), стратегічна альтернатива (концентрація, диверсифікація), конкурентні стратегіï (лідерство за витратами, диференціація), функціональні стратегії (фінансова, кадрова, антикризова, організаційна, інноваційна, управління якістю, ресурсна, зовнішньоекономічна, соціальна, екологічна, виробнича, маркетингова). Практичне впровадження механізму може забезпечити досягнення мети підприємства через реалізацію ієрархічного ланцюга «мета - фактори конкурентних переваг - стратегія - конкурентна перевага - конкурентоспроможність - результат». Запропонований підхід дозволяє визначати методи забезпечення конкурентоспроможності економічного суб'єкта як результату його активної ринкової політики, встановлювати причини та умови виникнення конкурентних переваг, розробляти на сформованій аналітичній базі конкурентні стратегії. Проаналізовано траєкторії шаблонного структурного розвитку успішних економічних суб'єктів на ринку, які схильні до збереження своєї організаційноі структури $i$, одночасно, зміни горизонтів існування створюють підгрунтя для трансформаціі структури як реакиї на ускладнення управлінських завдань. Як засіб реалізації стратегічноі альтернативи в упорядкованій системі стратегій підприємства запропоновано впровадження диверсифікації, яка розуміється як різноманітність результатів на ринку, а не виробництв всередині підприємства.

Ключові слова: диверсифікачія; конкурентна перевага; конкурентоспроможність; кониентрація; механізм; стратегія.

Актуальність теми. Основу процесу формулювання стратегії становить бажання компанії впоратися 3 конкуренцією. Компанії, незалежно від рівня галузевого суперництва, необхідно знайти таку позицію, в якій можливо протистояти дії ринкових конкурентних сил або використовувати їх для досягнення власних цілей. Знання причин конкурентного тиску дозволяє ідентифікувати фактори успіху компанії, визначити стратегії, які можуть принести максимальні результати, виявити напрямки, в яких тенденції розвитку обіцяють найбільш значні позитивні або негативні зміни у майбутньому. Обрана та реалізована стратегічна альтернатива стає підгрунтям для створення конкурентних переваг. Ці конкурентні переваги, в свою чергу, забезпечують конкурентоспроможність економічного суб'єкта, що дозволяє досягти його довгострокових цілей. Проблема формування конкурентних переваг, наряду зі значною увагою до неї, вивчена ще недостатньо. Практичний інтерес викликають методи досягнення переваги підприємства як результату його активної ринкової політики. Метою наукової роботи є пошук конкурентних переваг, причин та умов їх виникнення, розробка на сформованій аналітичній базі конкурентних стратегій.

Аналіз останніх досліджень та публікації, на які спирається автор. У межах теорії конкуренції методологічні підходи, які становлять наукову базу формування конкурентних переваг сформовані вітчизняними та зарубіжними вченими, серед яких Г.Азоєв, О.Челенков [1], І.Ансофф [8], Г.ПастернакТаранущенко, В.Рожок [3], Г.Ротанов [4], І.Саух [5]. Класична політекономія визначила принципи досконалої конкуренції, основу якої становить цінова система в абсолютно децентралізованій економіці. Моделі монополістичної, олігополістичної конкуренції та чистої монополії в межах неокласичної 
політекономії доводять з одного боку незалежність відносин суперництва на ринках від намірів суб'єктів ринку, з другого боку - залежність форми та інтенсивності конкуренції від суспільних процесів. У теорії інституціоналізму центральне місце займає проблема трансформації суспільства. Складовими механізму трансформації суспільства інституціоналісти вважають як економічні, так і соціальні, політичні, психологічні, морально-етичні фактори, активно досліджуються взаємовідносини монополії та конкуренції, управління динамікою цін, різні сторони господарського механізму [12].

Дослідники у галузі конкурентоспроможності по-різному оцінюють фактори успіху у конкурентній боротьбі. Сміт А. визначив, що основою конкурентоспроможності $є$ абсолютна перевага, яка грунтується на низьких витратах виробництва [6]. Розвиток ця концепція знайшла у роботах Д.Рікардо, який запропонував ідею відносних переваг, підгрунтя яких становить продуктивність праці [13]. Портер М. визначив, що конкурентоспроможність залежить лише від одного фактора продуктивності - кількості праці, необхідної для виготовлення товару [11]. Олін Б. розробив концепції, які в основу конкурентоспроможності покладають різницю факторів виробництва (землі, робочої сили, природних ресурсів, капіталу) при однакових технологіях [10]. Пастернак-Таранушенко Г., Рожок В. визначили, що теорія порівняльних переваг, яку розвинули ці вчені, відображає лише статику процесу, враховуючи три групи ресурсів (матеріальні, фінансові, трудові) і звернув увагу на необхідність обліку часового ресурсу [3, с. 8]. Дослідниками проблеми міжнародної конкурентоспроможності сформульовано два ключових положення теорії: а) конкурентні переваги можуть бути будь-якої якості - як об’єктивні умови господарської діяльності, так і умови діяльності окремих товаровиробників; б) рівень конкурентних переваг (конкурентоспроможність) не пов'язані з рівнем технології і з галузевою приналежністю виробника.

Метою статті є розробка концептуального підходу до стратегічного механізму забезпечення конкурентоспроможності економічного суб'єкта як практичного інструменту формування конкурентної політики підприємства 3 метою визначення і реалізації методів досягнення конкурентних переваг економічного об'єкта.

Методологічною основою дослідження є системний підхід до вивчення об’єкта, який доповнюється принципами класифікації, методами фінансово-економічного і портфельного аналізу. Системний аналіз грунтується на системному підході управління, який описує економічний суб'єкт у вигляді відкритої системи. Економічний суб'єкт-система має ієрархічну структуру, складається із взаємопов'язаних підсистем, через результати діяльності впливає на навколишнє середовище, та як споживач i постачальник ресурсів відчуває зовнішній вплив.

Викладення основного матеріалу. Дослідження доводять, що конкуренція як і будь-який ринковий механізм переживає трансформацію. Змінюються форми та методи конкуренції, перехід від галузевої до міжгалузевої, а з часом і до міжрегіональної та міжнародної [2]. Конкурентні процеси впливають на бажання економічного суб'єкта посилити конкурентоспроможність товарів та фірм, як на національному, так і на міжнародному ринках. У сучасній економіці формується тенденція до посилення ролі нецінової конкуренції як найбільш перспективного методу глобальної економічної конкуренції. У той самий час параметри конкурентоспроможності товару трансформуються в бік екологічності, естетичності, підвищення репутації. Новий етап трансформації висуває пріоритети потенціалу інтелектуальної людини. Серед критеріїв конкурентоспроможності якість трудових ресурсів випереджує показники якості продукції, технологій, ринкової орієнтації. Факторами конкуренції, яка у більшості випадків зводиться до прагнення завоювати найвигіднішу позицію, $є$ :

- значна кількість конкурентів у галузі, які приблизно рівні за розмірами та силою;

- темпи росту галузі сповільнюються, що робить жорсткішою боротьбу за частки ринку;

- продукція недиференційована;

- значні постійні витрати в середньому в галузі;

- нетривалий термін зберігання продукції, що провокує тиск в бік зниження цін;

- високі бар'єри при виході із галузі, що примушує менеджерів продовжувати низькорентабельний або зовсім збитковий бізнес;

- диференційовані стратегії і методи конкурентної боротьби різних учасників ринку.

Турбулентність середовища потребує від економічного суб’єкта швидкої реакції на зміни, які відбуваються у зовнішньому середовищі. Характеристики зовнішнього середовища являють собою набір факторів, які діють як на економічного суб'єкта, так і на ступінь зміни самих факторів. У таких умовах існують дві стратегії: адаптація до умов зовнішнього середовища та вплив на саме середовище для сприяння роботи організації. Як реакцію на зміни зовнішнього середовища стратегію забезпечення конкурентоспроможності можна розглядати в контексті адаптаційної стратегії підприємства, а як стимулятор зовнішніх змін - в аспекті ринкових взаємодій. Ланцюжок «ціль - фактори конкурентних переваг - стратегія - конкурентна перевага - конкурентоспроможність» дозволяє розглядати стратегію як підгрунтя досягнення конкурентних переваг в організації, тобто конкурентні переваги $є$ похідною від обраної і реалізованої стратегії. 
Використання системного підходу до дослідження стратегічного управління дало можливість авторові визначити те, що концепція стратегічного механізму забезпечення конкурентоспроможності економічного суб'єкта має охоплювати такі питання:

- обгрунтування можливості та необхідності управління процесами забезпечення конкурентоспроможності на рівні економічного суб'єкта;

- ідентифікація об'єкта і суб'єкта, видів стратегії забезпечення конкурентоспроможності;

- визначення методологічної основи управління стратегією забезпечення конкурентоспроможності економічного суб'єкта, в межах якої обгрунтовуються принципи та методи здійснення управління;

- розробка механізму управління стратегією забезпечення конкурентоспроможності економічного суб'єкта, складовими якого можуть стати підсистема формування конкурентної політики, підсистема реалізації конкурентної політики, підсистема оцінки соціально-економічного ефекту конкурентної політики;

- формулювання методичних засад формування складових управління стратегією забезпечення конкурентоспроможності економічного суб'єкта.

Взаємозв'язок між базовими положеннями поданої концепції ілюструє рисунок 1.

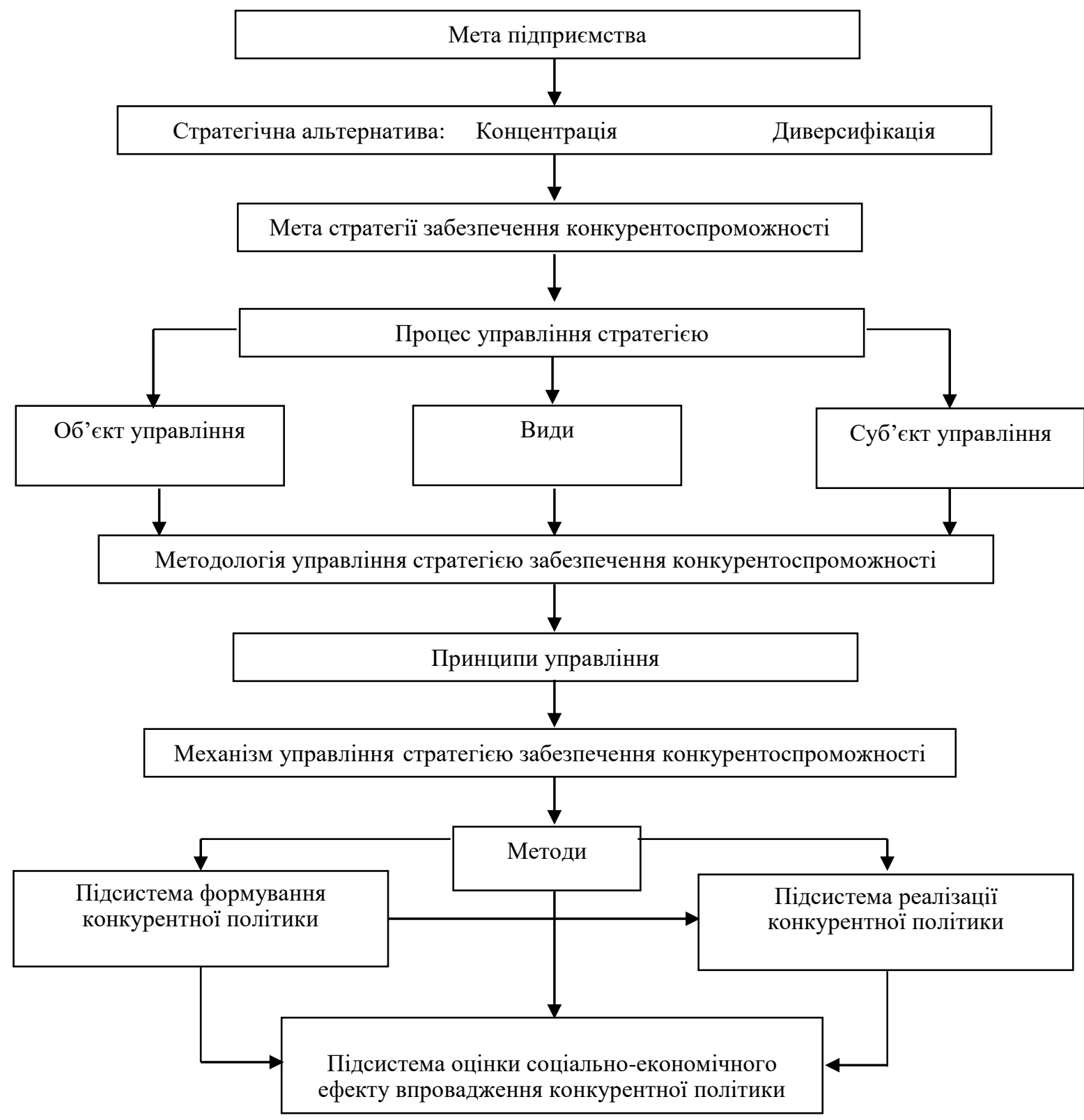

Рис. 1. Концептуальний підхід до стратегічного механізму забезпечення конкурентоспроможності економічного суб 'єкта 
Принципи регулюють процедурну сторону методики та методології стратегічного управління конкурентоспроможністю. Конкретизуємо загальні принципи стратегічного управління в контексті предмета нашого дослідження:

1. Мета підсистеми (стратегії) не вступає у конфлікт із глобальною метою системи (економічного суб'єкта).

2. Необхідність захищати вже отриманий і сформований капітал, а потім розробляти шляхи його збільшення і розвитку

3. Наявність хоча б одного не повністю завантаженого ресурсу.

4. Узгодження стратегічного напряму розвитку з потребами ринку.

5. Доцільність технологічної сумісності та спадкоємності.

6. Максимальне забезпечення наявних трудових ресурсів.

Питання стратегічного орієнтування закономірно виникають на певному ступені розвитку відтворюючого процесу за наявності відповідних передумов. Економічний суб'єкт визначає стратегічний напрям розвитку - концентрація/диверсифікація? - 3 урахуванням дії економічних законів та закономірностей, таких як: закон спадаючої корисності, закон зростаючих витрат, закон спадаючої віддачі (закон масового виробництва), закон нерівномірного розвитку економіки, диверсифікація, концентрація, закон накопичення та перенакопичення, закон тенденції прибутку до зниження, закономірності розвитку науково-технічного прогресу. Виходячи зі стратегічної мети, економічний суб'єкт вирішує доцільність політики концентрації або диверсифікаційної політики, напрям і галузь проведення, а також обсяги витрат (рис. 2).

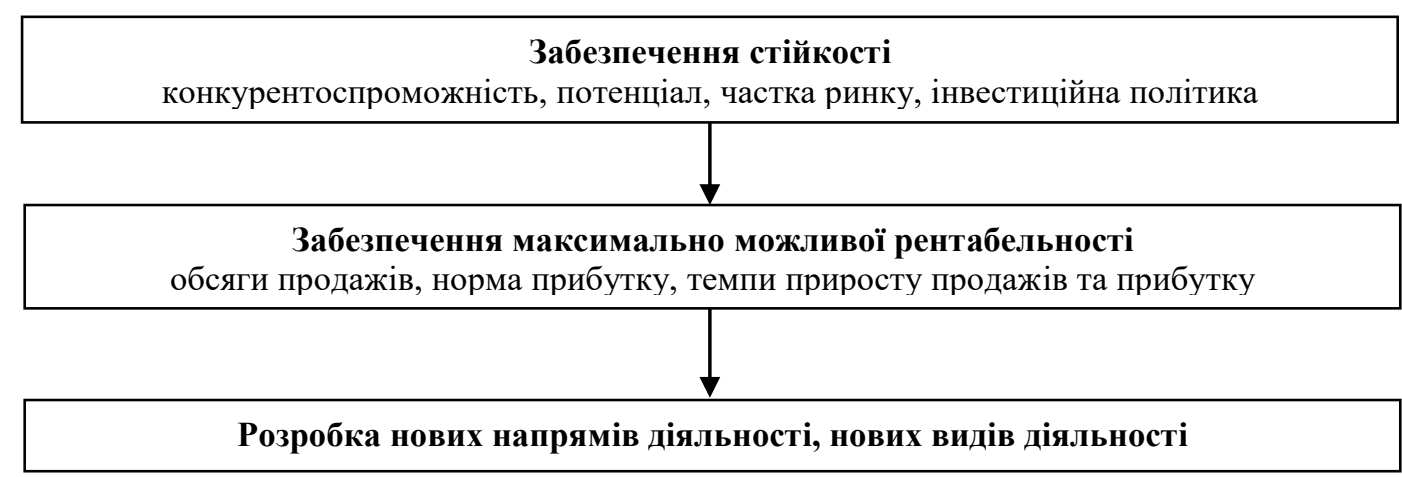

Рис. 2. Ранжування цілеей економічного суб'єкта

Відповідно до запропонованих структуризацій цілей та розподілу компанії на організаційноуправлінські рівні, наведено ієрархію стратегій (рис. 3).

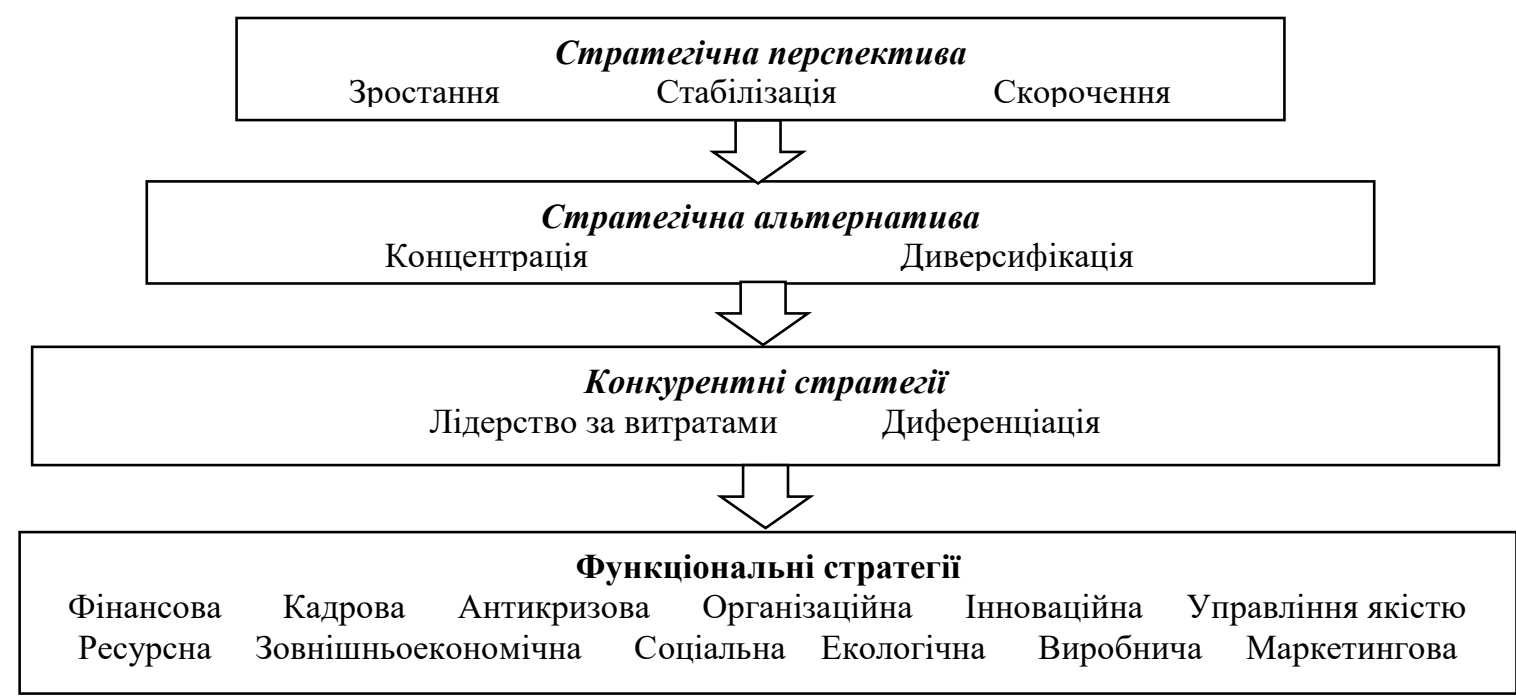

Рис. 3. Ієрархія стратегій економічного суб'єкта 
Найвищий рівень системи стратегічного процесу - це стратегічна перспектива (або «стратегічне бачення» за А.А. Томпсоном та А.Дж. Стриклендом [7, с. 47]), яку можна розглядати як усвідомлення організацією свого місця на ринку та прийняття рішення щодо продовження курсу або його зміни.

На другому рівні (корпоративному) компанія, яка працює на ринку, незалежно від розмірів та галузі, має вибрати стратегічну альтернативу: концентрація зусиль або диверсифікація. Ця стратегія визначає організацію в цілому, іiі стратегічні одиниці, комбінація яких дозволяє відповісти на запитання: яким бізнесом організація займається?

На корпоративному рівні вирішуються питання організації нових стратегічних одиниць, розширення або згортання наявного бізнесу. Корпоративна стратегія проявляється в тому, як компанія підтверджує свої ділові принципи в різноманітних галузях, а також у діях та підходах, спрямованих на поліпшення діяльності груп підприємств, у які диверсифікувалася компанія.

Економічні суб’єкти вважають за краще мати збалансований набір стратегічних одиниць. Спочатку формується основоположна стратегія компанії, потім за допомогою портфельної стратегії складається портфель із декількох стратегічних одиниць. Центр розглядається як банкір, який вибирає об'єкт інвестування грошей задля довгострокової конкурентної переваги. Це викликає потребу у певній класифікації складових бізнесу в загальному портфелі.

Визначивши пріоритети, необхідно розробити стратегію, яка найбільше враховує розвиток ринкової ситуації і використовує потенціал підприємства. Конкурентна стратегія (рівень стратегічної одиниці) належить до кожної сфери бізнесу та визначає прийоми й методи конкурентної боротьби окремої бізнесодиниці за ринок і покупців. Вона дає відповідь на питання: як організація конкурує? На цьому рівні приймаються рішення щодо обсягів виробництва, напрямів та масштабів досліджень, створення нових продуктів. Основне завдання стратегії бізнес-одиниць - безпосередня участь у конкурентній боротьбі. Основоположний напрям діяльності залишається незмінним (зростання, стабілізація, скорочення), однак реалізується в методах конкуренції через лідерство за витратами або диференціацію продукції.

Стратегії найнижчого рівня (функціональні) спрямовані на формування конкурентних переваг кожного функціонального підрозділу організації. Вони дають відповідь на запитання: яким чином підтримується стратегія бізнес-одиниць? Стратегія цього рівня являє собою плани дій основних відділів організації, мета яких забезпечення реалізації конкурентної стратегії. Функціональна стратегія створює конкретні орієнтири досягнення цілей, що підлягають вимірюванню. До ключових функціональних стратегій зараховують виробничу, маркетингову, фінансову, інноваційну, соціальну, екологічну, кадрову, антикризову, організаційну, з управління якістю, ресурсну, зовнішньоекономічну.

Існують важливі організаційні та управлінські переваги концентрації зусиль на одній сфері діяльності. По-перше, увага менеджменту цілком концентрується на досягненні постійної відповідності стратегії фірми будь-яким змінам в галузі. По-друге, бізнес в одній сфері стимулює посилення конкурентних переваг компанії для забезпечення виживання у довгостроковій перспективі. Керівництво сконцентроване на покращенні технології виробництва, ефективності ланцюга «виробництво - витрати». У той самий час існує ризик концентрації зусиль на одному виді діяльності, у випадку, якщо галузь 3 якихось причин перестає бути привабливою (наприклад, внаслідок зміни потреб споживачів, появи товарів-субститутів в інших галузях, появи нових технологій). Це є причиною впровадження стратегії диверсифікації, навіть при успішному розвитку основного виду діяльності компанії.

Незалежно від загального напряму розвитку (стратегія стабілізації, росту, скорочення), організація може диверсифікувати діяльність. Кожна із стратегій диктує підприємству свою політику в галузі диверсифікації. Стратегія стабілізації передбачає зміни в номенклатурі та ринках за тих самих обсягів продажів та прибутків. При стратегії скорочення диверсифікація викликана скороченням попиту на традиційну продукцію, інвестиції направлені на випуск продукції іншої асортиментної групи. Стратегія росту передбачає можливу зміну як номенклатури продукції, так і ринків збуту за умови росту обсягів реалізації та прибутку. Компанія, яка втілює стратегію росту має дві стратегічні альтернативи: концентрація зусиль на одному виду діяльності або диверсифікація діяльності. Компанія, яка обирає диверсифікацію, має визначити, буде це диверсифікація в родинні галузі, в інші непов'язані з основною діяльністю галузі або комбінація цих двох підходів. Перевага віддається стратегії росту як єдиної, що повністю відповідає цілям підприємництва, тобто забезпечує функціонування підприємства в умовах ринку. Стратегія стабілізації та скорочення має супідрядний характер, їх необхідно реалізовувати в мінімально короткий час, метою цих стратегій повинен стати перехід підприємства до стратегії росту.

Опрацювання концепцій розвитку організації [7-9; 11] дозволило визначити тенденцію до шаблонного розвитку організаційних структур економічних суб'єктів. Більшість компаній починають свою діяльність як вузькоспеціалізовані підприємства 3 обмеженим асортиментом продукції. Перетворення функціональної організації в диверсифіковану проходить у чотири етапи. На початковому етапі підприємство має вигляд безперервного ланцюжка, який з'єднує постачання сировини, виробництво одного виду продукції, реалізацію. Наявність незавантажених ресурсів створює передумови для товарної експансії. Виникає форма виробництва побічного продукту, при якій використовується 
вертикальна інтеграція, в більшості випадків зворотна, побудована на використанні однієї сировини. Диверсифікація ринків побічної продукції призводить до збільшення обсягів виробництва, підвищення значення неосновних підрозділів. У момент, коли обсяг виробництва побічної продукції є не меншим за обсяг виробництва основної продукції, компанія знаходить форму взаємопов'язаних продуктів. У подальшому збільшення обсягів продажу відбувається за рахунок географічної експансії у такій послідовності: місцевий - регіональний - національний - міжнародний ринок. Наступним етапом підвищення ефективності діяльності компанії є диверсифікація в інші галузі.

Диверсифікація - це агресивна стратегія освоєння нових напрямів діяльності підприємства, яка дозволяє досягти стратегічних цілей організації: виживання та підвищення ефективності виробництва у довгостроковій перспективі, збільшення норми прибутку - у короткостроковій перспективі шляхом створення нових підприємств або реорганізації вже існуючих. Метою диверсифікації є формування товарних ліній, які б сприяли ефективному розвитку підприємства за рахунок багатосторонньої діяльності.

Визначимо два загальні напрями диверсифікації:

- диверсифікація діяльності підприємства. Внутрішній ріст передбачає диверсифікацію існуючого підприємства за рахунок використання ресурсів організації. У компанії існують дві можливості внутрішньі диверсифікації: створення продукції, подібної до існуючої, та створення зовсім нової продукції. Компанія може диверсифікувати ринки або технології. Головною причиною внутрішньої диверсифікації компанії є надлишок ресурсів (матеріальних, технологічних, людських, фінансових), які можна використати у виробництві нової продукції для отримання додаткового прибутку. Метою внутрішньої диверсифікації є створення основи для забезпечення виживання компанії у майбутньому;

- диверсифікація через злиття та поглинання. Зовнішній ріст передбачає з’єднання підприємств, пов'язаних технологічним ланцюжком або непов'язаних. До переваг необхідно зарахувати відпрацьовані технології, наявність функціональних зв’язків з постачальниками, популярність продукції, імідж, канали збуту, кваліфікований персонал, тобто значно менший обсяг додаткових інвестицій. При зовнішньому рості компанія постає перед вибором: придбати успішне підприємство за високу ціну або низькорентабельне більш дешеве підприємство. Вибір залежить від власних фінансових можливостей та потенціалу. Створення підприємств через злиття народжує організації з міцним фінансовим потенціалом та конкурентною позицією. Однак між учасниками нерідко виникають протиріччя з приводу контролю над грошовими потоками та розподілу прибутку. Зовнішня диверсифікація дозволяє підприємству отримати ряд переваг: розширити асортимент продукції; зменшити конкуренцію за рахунок придбання суперника; здійснити ріст швидше, ніж при внутрішній диверсифікації; оптимізувати доходи та витрати підприємств; урівноважити циклічність виробництва і продажів; збалансувати піки в життєвих циклах товарів; забезпечити віддачу вільних капіталів; знизити ризик інвестиційного портфеля.

Непов'язана диверсифікація означає інвестування ресурсів у більшості випадків в галузі з високими темпами росту та високим рівнем ризику. Таким чином, 3 одного боку, диверсифікація дозволяє розподілити ризики інвестиційного портфеля, з другого - робота у нових сферах бізнесу пов'язана 3 високими ризиками. Через це робота у традиційній сфері може бути більш прибутковою та менш ризикованою. Неспівпадання прибутків та збитків, які отримує диверсифікована компанія від різних бізнес-одиниць, у часі дають можливості для маневрування, оптимізації витрат на постачання, оптимізації маси та норми прибутку. Зіставляючи показники конгломератів та синергетичних компаній, І.Ансофф зауважує, що показники компаній однакові в стабільній економіці, але в періоди спаду кон'юнктури ринку синергетичні компанії дають кращі результати [8].

Методи реалізації стратегії забезпечення конкурентоспроможності:

- сегментація товарного ринку і пристосовування до потреб покупців сегментів, вибраних для ринкової експансії;

- вторгнення на суміжні або раніше не охоплені ринки;

- нарощування експорту (навіть шляхом продажу за демпінговими цінами);

- пристосовування асортименту товарів до особливостей попиту платоспроможних груп покупців на внутрішньому ринку;

- створення власних збутових каналів для компенсації слабкостей вітчизняної торгової мережі;

- вертикальна та горизонтальна інтеграція;

- створення конгломератів.

Реалізація конкурентної політики досить часто передбачає реструктуризацію підприємства, яка полягає в здійсненні реорганізаційних заходів для приведення функціональних структур у відповідність до виробленої стратегії розвитку. Метою реструктуризації стає поліпшення управління, підвищення ефективності виробництва, конкурентоспроможності продукції, що випускається, зростання продуктивності праці, зниження витрат виробництва, поліпшення фінансово-економічних результатів діяльності. Економічні суб'єкти, які функціонують на розвиненому ринку, не потребують кардинального перегляду стратегій і політики. В умовах перехідного суспільства така перебудова є об'єктивно необхідною і має торкатися усіх функціональних підсистем організації. 
Ефективність стратегії оцінюється, виходячи із конкурентного стану підприємства в цілому. При всій складності та неоднозначності питання вибору стратегічної альтернативи зроблено загальний висновок на підставі досліджень робіт вчених: суто теоретично найбільш ефективною $є$ стратегія концентрації діяльності; при рівних умовах пов'язана диверсифікація має перевагу над непов'язаною (конгломератною); внутрішній ріст має перевагу над ростом через злиття та поглинання. Останнім часом у менеджменті з'явилася теорія «від'ємного синергізму», протилежна теорії об'єднання зусиль. Проте не слід вважати будьяке диверсифіковане утворення помилкою. Продумана диверсифікація, яка заснована на ефекті різноманітності, $є$ перспективним шляхом розвитку сучасного крупного виробництва. Основою для цього є:

1. Постійний пошук можливостей розподілу виробництв у вже існуючих структурах, що дозволяє освоїти нові види бізнесу та спростити диверсифікацію.

2. Визначення слабкості технологічного процесу та життєвого циклу товару, які можуть вказати на потрібні напрями диверсифікації.

3. Визначення економічного потенціалу нового бізнесу. Дослідники вважають, що нова сфера бізнесу не має бути привабливою до моменту диверсифікації.

4. Використання практичного досвіду, накопиченого в основній сфері бізнесу.

5. Спрощення горизонтальних зв’язків між бізнес-одиницями, створення механізму корпоративної єдності.

Висновки та перспективи подальших досліджень. Система дій економічного суб'єкта на ринку спрямована на монополізацію ринку для максимізація прибутку, проте досягти цього в сучасних умовах практично неможливо. Фірма має передбачити у своїй діяльності одночасно принаймні два стратегічні напрями - монополізацію ринку і зменшення кількості конкурентів, та інтеграцію своєї діяльності й зменшення ступеня ризику за рахунок співробітництва з іншими фірмами в різноманітніших формах. Дія у цих двох напрямах - полістратегічний пошук - типове явище для країн 3 розвинутою ринковою економікою, в яких конкуренція і монополія завжди були як парні характеристики. Необхідність суперництва за досягнення монопольного становища, неможливість припинення конкурентної боротьби i водночас неможливість монополізації ринку призводять до використання таких форм концентрації виробництва і капіталу на міжгалузевому рівні, як інтеграція і диверсифікація. На перших етапах монополізується окремий вид виробництва, галузь промисловості (горизонтальна диверсифікація) або ж послідовно сполучені виробництва (вертикальна диверсифікація). В умовах нагромадження капіталу пошуки шляхів прибуткового застосування капіталу породжують складну форму концентрації виробництва - конгломератну диверсифікацію.

Корпоративна стратегія розвивається в межах між концентрацією, вертикальною інтеграцією та інтернаціоналізацією і має ряд етапів, які відрізняються набором елементів у розпорядженні економічного суб'єкта (види виробництва, галузі, сфери діяльності). При зміні кількісних та якісних показників виробництва процес постійно набуває нових рис, нових тенденцій. Кожен етап виходить із попереднього, вбирає в себе характеристики досягнутого раніше рівня, одночасно набуваючи нових елементів. Процес можна зобразити у вигляді циклічної спіралі, яка охоплює такі сторони діалектичного розвитку, як спадкоємність, повторюваність, висхідний характер руху. Разом 3 тим, кожен новий виток спіралі є більш високим ступенем розвитку. Низка витків характеризує нескінченність розвитку диверсифікації, розвиток від нижчого до вищого. Старий набір заперечується та поповнюється новими елементами у розпорядженні підприємства.

Диверсифікація являє собою одну 3 можливих стратегій розвитку задля досягнення довгострокової мети підприємства. Процес управління диверсифікацією включає встановлення об'єкта та суб'єкта диверсифікації, визначення видів диверсифікації як засобів досягнення різноманітних цілей при диверсифікації діяльності підприємства. Одним із елементів процесу пропонуємо вважати дії по формуванню методології управління диверсифікацією. Механізм управління диверсифікацією базується на принципах i методах управління, забезпечує соціально-економічний ефект при впровадженні диверсифікації через формування та реалізацію диверсифікаційної політики.

Вибір і реалізація стратегії конкуренції не гарантує автоматичний успіх на ринку. Це в першу чергу пов'язане 3 динамізмом ринкового середовища, різноманітністю ситуацій, складністю стратегічного управління і призводить до великої кількості помилок, які допускаються керівниками при виборі стратегії. Відсутність практичних рекомендацій в українській науковій літературі призводить до нагальної потреби в розробці рекомендацій по конкретизації стратегій конкуренції в чітко визначених умовах господарювання.

Список використаної літератури:

1. Азоев Г.Л. Конкурентные преимущества фирмы / Г.Л. Азоев, А.П. Челенков. - М. : ОАО «Типография Новости», 2000. - $256 \mathrm{c}$.

2. Білорус О.Г. Соціальна глобалістика: економіко-правові імперативи / О.Г. Білорус [Електронний ресурс]. Режим доступу : http://dspace.nbuv.gov.ua/bitstream/handle/123456789/39574/03-Bilorus.pdf?sequence=1. 
3. Пастернак-Таранущенко Г. Конкуренция. Курс лекций и практических занятий / Г.Пастернак-Таранущенко, В.Рожок. - К. : ЦУЛ, 2002. - 322 с.

4. Ротанов Г.М. Стратегія управління конкурентоспроможністю промислового підприємства / Г.М. Ротанов // Вісник ЖДТУ. Економічні науки. - Житомир : ЖДТУ, 2013. - № 1 (63). - С. 316-319.

5. Cayx I.B. Стратегічний аналіз: уточнення категоріально-понятійного апарату / I.B. Cayx // Вісник ЖДТУ. Економічні науки. - Житомир : ЖДТУ, 2014. - № 4 (70). - С. 31-38.

6. Смит А. Исследование о природе и причинах багатства народов / A.Смит. - М. : Эксмо, 2007. - 960 с.

7. Томпсон A.A. Стратегический менеджмент. Искусство разработки и реализации стратегии / A.A. ${ }^{\circ}$ Томпсон, А.Дж. ${ }^{\circ}$ Стрикленд ; пер. с англ. - М. : Банки и биржи ; ЮНИТИ, 1998. -576 с.

8. Ansoff I. Corporate Strategy / I.Ansoff . - Middlesex : Penguin Books, 1981.

9. Mintzberg H. Structure in Fives Englewood Cliffs / H.Mintzberg. - NJ : Prentice Hall, 1989.

10. Ohlin B. The Market Economy and the Third World - Is a Liberal Alternative Possible? / B.Ohlin // The Rich and the Poor. An International Colloquium. - Stockholm, 1975.

11. Porter M.E. Competitive Advantage: Creating and Sustaining Superior Performance / M.E. Porter. - New York : Free Press, 1998.

12. Radieva M. Institutional modernization of the global economy / M.Radieva // Baltic Journal of Economic Studies. - 2018. - № 4 (5). - P. 283-291.

13. Ricardo D. On the Principles of Political Economy and Taxation / D.Ricardo [Електронний ресурс]. - Режим доступу : https://books.google.com.ua/books?id=cUBKAAAAYAAJ\&dq=editions:y8vXR4oK9R8C\&pg=PR1\&re dir_esc $=\mathrm{y} \# \mathrm{v}=$ onepage $\& \mathrm{q} \& \mathrm{f}=$ true.

\section{References:}

1. Azoev, G.L. and Chelenkov, A.P. (2000), Konkurentnye preimushhestva firmy, Tipografija Novosti, M., 256 p.

2. Bilorus, O.G., Social'na globalistika: ekonomiko-pravovi imperativi, [Online], available at: http://dspace.nbuv.gov.ua/bitstream/handle/123456789/39574/03-Bilorus.pdf?sequence=1

3. Pasternak-Taranushhenko, G. and Rozhok, V. (2002), Konkurencija. Kurs lekcij i prakticheskih zanjatij, CUL, K., 322 p.

4. Rotanov, G.M. (2013), «Strategija upravlinnja konkurentospromozhnistju promyslovogo pidpryjemstva», Visnyk ZhDTU. Ekonomichni nauky, ZhDTU, Zhytomyr, No. 1 (63), pp. 316-319.

5. Sauh, I.V. (2014), «Strategichnyj analiz: utochnennja kategorial'no-ponjatijnogo aparatu», Visnyk ZhDTU. Ekonomichni nauky, ZhDTU, Zhytomyr, No. 4 (70), pp. 31-38.

6. Smit, A. (2007), Issledovanie o prirode i prichinah bagatstva narodov, Jeksmo, M., 960 p.

7. Tompson, A.A. and Stryklend, A.Dzh. (1998), Strategycheskyj menedzhment. Yskusstvo razrabotky y realyzacyy, strategyy, Banky y byrzhy, JuNYTY, M., $576 \mathrm{p}$.

8. Ansoff, I. (1981), Corporate Strategy, Penguin Books, Middlesex.

9. Mintzberg, H. (1989), Structure in Fives Englewood Cliffs, Prentice Hall, NJ.

10. Ohlin, B. (1975), «The Market Economy and the Third World - Is a Liberal Alternative Possible?», The Rich and the Poor. An International Colloquium, Stockholm.

11. Porter, M.E. (1998), Competitive Advantage: Creating and Sustaining Superior Performance, Free Press, New York.

12. Radieva, M. (2018), «Institutional modernization of the global economy», Baltic Journal of Economic Studies, No. 4 (5), pp. 283-291.

13. Ricar, D., On the Principles of Political Economy and Taxation, [Online], available at : https://books.google.com.ua/books?id=cUBKAAAAYAAJ\&dq=editions:y8vXR4oK9R8C\&pg=PR1\&redir_es $\mathrm{c}=\mathrm{y} \# \mathrm{v}=$ onepage $\& \mathrm{q} \& \mathrm{f}=$ true

Радєва Марина Миколаївна - доктор економічних наук, професор Мелітопольського інституту державного та муніципального управління «Класичного приватного університету».

orcid.org/0000-0003-2288-3388

Наукові інтереси:

- інституціональне забезпечення сталого розвитку сучасної економіки.р 